\title{
The Beginnings of the Progressive Movement in Iowa
}

\author{
By Fleming Fraker Jr.
}

The administration of Leslie M. Shaw (1898-1902) may be termed the end of an era in Iowa political history. He was the last governor in a political dynasty that was in close harmony with the corporate interests which came to dominate economic life and public affairs in the state soon after the Civil War. A determined progressive movement within the Republican party successfully breached the almost complete control heretofore exercised by several near monopolies, chiefly the railroads.

Iowa's agricultural and commercial development was largely dependent upon the railroads. Favorable tax rates and liberal grants of land encouraged the building of the first connecting lines between interior points and the river towns of Dubuque, Clinton, Davenport, Muscatine, Burlington, Fort Madison and Keokuk. But much of Iowa had to wait for the great expansion of the national economy that came after the Civil War to get an adequate and dependable transportation system. ${ }^{1}$

The need and demand for a railroad network throughout the state put their promoters in a commanding position. To protect and facilitate the profitable operation of their expanding enterprises, which provided almost indispensible public services in that day, these forceful men perfected the most efficient organization to control state and national government that had been seen to date. The selection and election to public office of individuals sympathetic to their interests eliminated their only real fear, effective government regulation.

Iowa was one of the first states to revolt. The selection of the progressive candidate, Albert B. Cummins, as the Republican nominee for governor at the Republican state convention in

1 George H. Miller, "Origins of the Iowa Granger Law," The Mississippi Valley Historical Review, XL (March, 1954), 660-661. As late as 1865, Iowa had only 891 miles of railroad. Illinois in the same year, had 3,157 miles. 
Cedar Rapids, August 7, 1901, is seen as the first significant defeat suffered by the "standpatter crowd" in over thirty years. $^{2}$

Early in the 1870's the state's ruling Republican party was quietly captured, in part by a discriminating use of the free pass and the rebate. Until almost the turn of the century, the aspirant that succeeded to important state office without the approval of Nathaniel M. Hubbard, Iowa attorney for the Chicago \& Northwestern Railway Co. and Joseph W. Blythe, general counsel for the Chicago, Burlington and Quincy Railroad Co., was rare indeed. The organization and techniques devised by these two master political strategists for many years operated efficiently on all levels from the precinct caucus to the United States Senate. Their tremendous prestige and constant propaganda advertising their good works enabled the corporations to be identified in the public mind with good government, personal success, and respectability.

There had been agitation for relief from rate discrimination and other flagrant abuses of monopolistic power long before the threat of a third term for Governor Shaw brought forth a strong progressive faction to prevent it. Men like General J. B. Weaver, Governor C. C. Carpenter, and Governor William Larrabee individually sought to free their party from this outside domination and advocated legislation to regulate corporate activities. The first Granger law was passed March 19, 1874 during Carpenter's administration (1872-1876), setting maximum rates. But party leaders blocked Weaver's strong bid to succeed Carpenter when they placed the name of the popular old wartime governor, Samuel J. Kirkwood before the state convention in $1875^{3}$. Weaver left the Republican party and sought other means of securing the changes in which he believed, but with limited success.

The establishment of a railroad commission in 1878 was another effort to regulate railroad rates in the public welfare. But it was given only advisory powers, and when popular feeling died down and other issues arose, any benefits were

2 Emerson Hough, "Cummins of Iowa," The National Daily Review, October 19, 1905, p. 1.

3 James S. Clarkson, "The Stampede From General Weaver in the Republican Convention of 1875," ANNals of Iowa, First Series, X (January, 1913), pp. 562-69. 
largely nullified by officials who owed their position to Hubbard and Blythe. ${ }^{4}$

Ex-governor Larrabee (1886-1890) anticipated many of progressivism's tenents in his study, The Railroad Question, which apeared in 1893 . He seems to have been profoundly disturbed by the dictatorial methods of the corporations, particularly exemplified in the Glenwood case ${ }^{5}$, after learning the true state of affairs during his two terms in office. He strongly supported legislation enacted by the Twenty-second General Assembly under the leadership of Polk County representative James G. Berryhill, chairman of the House Appropriations Committee, strengthening the railroad commission. Observing the realities of political power in this same session of the legislature, was a brilliant young lawyer of independent mind by the name of Albert Cummins.

During the Allison era as the period is sometimes called, Iowa produced as able a group of public men as the state has ever known. Senator William B. Allison, elected in 1873, inherited leadership of the powerful "Dodge \& Co." regime and exercised great influence in the United States Senate for over thirty years. Albert Cummins, after leading the progressive's fight to break the hold of the old order in the state, finally achieved his greater ambition in succeeding to the venerable old Iowa senator's seat in 1908.

Their party leaders' close accord with big business probably was partially responsible for the prominence of several other capable Iowans such as Col. William P. Hepburn, congressman from the Eighth District; Col. David B. Henderson, congressman from the Third District; George D. Perkins, congressman from the Eleventh District and editor of the Sioux City Journal; Senator and former Governor John H. Gear; Capt. J. A. T. Hull, congressman from the Seventh District; J. F. Lacey, congressman from the Sixth District; and Senator Jonathan P. Dolliver.

4 Fred E. Haynes, Third Party Movements Since the Civil War, 1916, p. 444 .

5 The Burlington Railroad was charging the state the total of the through rate on carload shipments of coal from the Illinois fields to Omaha plus the local rate from Omaha back to Glenwood, although the cars were switched from the trains at Glenwood and not taken to Omaha. 
The railroads came to own vast properties, pay substantial though disproportionate taxes, and employ thousands of workers in Iowa. William Larrabee states they "received as donations from various sources a value of over fifty million dollars." 6 In every community the more able lawyers and most competent physicians were retained by them, adding to their prestige and authority in all the ramifications of political and economic life in the state.

Their accommodating peremptoriness and arbitrary policies naturally came to be resented by a good many people, depending of course upon the degree to which a man was affected by their activities. Perceptive individuals began to realize political freedom was a thing of the past. Charges of favoritism and too friendly relations with railroad managers were made more frequently. The issue inevitably shifted into politics with more candidates declaring themselves, and splitting into railroad and anti-railroad partisans.

The "grand old party" was so divided by the liquor question in 1889 that the governorship was lost to the Democratic candidate, Horace Boies. The well-known thirteenth plank ${ }^{7}$ enabled the Republicans to close ranks for the 1893 campaign, and regain their traditional control of state affairs with Frank D. Jackson (1894-1896) as governor.

Perhaps symptomatic of the fact that others were learning how to operate the intricate caucus system, was the election of an independent Republican, Cornelius G. McCarthy from Nevada in Story county, as state auditor in November of 1892. This post entitled him to membership on the important fourman executive council which, at that time, assessed the corporations for tax purposes.

Opposition to the Blythe-Hubbard regime was isolated and ineffective, but it persisted and slowly gained momentum. A few zealous newspapermen in the northern part of the state helped to fan the flames of reform. One of the first to "tear the mask of respectability from the railroad pass" and point

6 From his second inaugural address in 1888.

7 From an unpublished manuscript by Emory H. English in the files of the Iowa State Department of History and Archives. It declared that the attitude of any Republican upon the prohibitory question should not be a test of party fealty. 
out its true purpose, was A. B. Funk, publisher of the Spirit Lake Beacon. ${ }^{8}$

The monopoly issue came up again in 1894. Senator James F. Wilson declined to run for a third term in the United States Senate. Albert Cummins desired the office, having achieved widespread recognition in the years following his victory over the barbed-wire trusts in $1881^{9}$ and needing a new field in which to exercise his considerable talents. He presented himself in the regular way along with such men as former-Governor John H. Gear (1878-1882), George D. Perkins, J. F. Lacey, W. P. Hepburn, and L. S. Coffin, to the Republican party leaders as a candidate to succeed Senator Wilson. Despite his unquestioned ability and popularity, Cummins' independent record made him unacceptable to the corporate interests in command. There was little organized opposition in the Republican caucus to the naming and subsequent election of a safe candidate in the person of Blythe's fatherin-law, John Henry Gear.

This initial defeat in his bid for high office did not deter Cummins. He worked hard to prepare himself for the next opportunity, because Gear was an old man and in all likelihood would not succeed himself. Chosen a member of the Republican National Committee from Iowa, Cummins threw himself wholeheartedly into the 1896 presidential campaign to secure the election of William McKinley. The energetic Iowan's political vision was considerably broadened by close association with such men as Charles G. Dawes, Henry C. Payne, Theodore Roosevelt, and Mark Hanna. ${ }^{10} \mathrm{He}$ saw and helped exercise the immense power of patronage. And the desire to be a United States senator remained stronger than ever.

Leslie M. Shaw was a lawyer and a banker in Denison, Iowa, a relatively unknown figure in the state before being brought forth as Judge Hubbard's choice for governor in 1897. A captivating speaker, able to convince the most obtuse

8 Thomas J. Bray, The Rebirth of Freedom, 1957, pp. 39-41.

${ }^{9}$ Ibid., pp. 56-57.

10 Elbert W. Harrington, "Political Ideas of Albert B. Cummins," The Iowa Journal of History and Politics, XXXIX (October, 1941), pp. 344-345. 
audience in his advocacy of sound money, he had been an effective counter to William Jennings Bryan's eloquence on behalf of free silver the previous year. But few voters outside of his own county were acquainted with this friendly, personable storyteller. ${ }^{11}$

Much of the Eleventh District in northwest Iowa under the tutelage af A. B. Funk's crusading Spirit Lake Beacon, was in open rebellion against the machine control of the old dynasty, sending many progressives to the state conventions, the legislature, and the county court houses. There was the possibility these radicals might capture the entire Tenth District, too. Other editors who were not obligated for free passes or postmasterships, began to be more outspoken in denouncing special privilege in government. Billy Hamilton of the Odebolt Chronicle, John C. Kelley of the Sioux City Tribune, and the Stauffer brothers with the Sac City Sun joined Funk at an early date to aggressively urge united action in Republican nominating conventions. ${ }^{12}$

Funk learned the methods of political organization during his three terms in the state senate (1888-1900). Now this vast knowledge, and his dedication to honest government stood him in good stead. His forceful editorials and the respect which he had long been accorded in his party, attracted the support of many who were of similar mind. At the 1897 Republican state convention progressive strength consolidated behind Funk to make him a leading candidate to succeed Governor Francis M. Drake (1896-1898). To meet this threat to its continued domination of party affairs, the machine "suggested" Shaw as potentially the stronger candidate over such old dependables as lieutenant-governor Matt Parrott, former-congressman William E. Fuller and others. The conservative rank and file obediently swung into line.

Judge J. P. Conner of Denison went to Boone county to ask support for Shaw. Charles Mason and John L. Stevens, to whom he appealed, said if Shaw would pledge himself to Cummins for United States senator they would help him get

11 From an unpublished manuscript in the files of the Iowa State Department of History and Archives, "Shaw's Entry into Public Life," by E. H. English.

12 Bray, op.cit., p. 41. 
Boone county. The pledge was made by Judge Conner and later confirmed by Shaw. ${ }^{13}$

The coup which engineered the nomination of Leslie $M$. Shaw occasioned some bitterness among the defeated candidates. The railroad politicians and federal officeholders beat them with an unknown. Parrott wanted the nomination, and it had been assumed he would get it. Funk believed that several Woodbury county delegates switched their votes to Shaw under the influence of Judge Hubbard's good friend, former congressman George Perkins and his associate publisher of the Sioux City Journal, Ed P. Heizer. ${ }^{14}$ Shaw proved a popular and able candidate, easily winning the election in November of 1897. But the power of the "standpatter crowd" that made him governor had been challenged, and that challenge was to grow stronger.

The opposition to the Republican party chieftains at this Cedar Rapids convention was really more of a preliminary skirmish. However, a pronounced division in Republican party ranks was now generally recognized. Progressive leaders found that it took machine methods to combat a machine. And they were learning how to manipulate and control precinct caucuses and county conventions with organization. More newspapers joined their cause, instructing voters on the principles involved and the measures necessary for regaining control of their party. Editors such as Monte Hunter of the Webster City Freeman-Journal; Ira Nichols of the Iowa Falls Citizen; William Orchard of the Glidden Graphic; Fritz (D. W.) Norris of the Grinnell Register and later the Marshalltown Times-Republican; the Beal brothers with the Mount Ayr News; William Gray of the Clear Lake Mirror; Chas O. Carter of the Boone News; and the Hartmans with the Waterloo Courier played an important part in stimulating state-wide progressive sentiment. The "Boxer Rebellion," as it was dubbed by Hubbard and Blythe in the early days, was in firm control of the Tenth and Eleventh Districts by 1900. And it rapidly

13 "A Statesman's Career," The Sioux City Daily Tribune, January 17, 1901, Editorial, p. 4.

14 Emory H. English, "Shaw's Entry into Public Life," an unpublished manuscript in the files of the Iowa State Department of History and Archives. 
developed strength in the Second, Third, Fourth, and Seventh Districts. Delegate and legislative inroads were even being made in the Sixth, ${ }^{15}$ Eighth, and Ninth Districts, much of which was called Blythe's "reservation" because the Burlington right-of-way ran through this southern tier of counties.

It took time to make much of a showing in the Fifth and First Districts, which constituted "standpatter" strongholds as Hubbard and Blythe made their homes there in Cedar Rapids and Burlington respectively. They also had the advantage of being in control of the state government and the Republican State Central Committee, besides having as their adherents in Washington, Senator Allison, Senator Gear, and nine of Iowa's eleven congressmen. ${ }^{16}$

Thus by the beginning of the century the scene was set for an epic struggle for leadership of the Republican party in Iowa and the political power that victory would assure. Related reforming movements were beginning to make themselves felt in other states and in national affairs.

For some time the progressives had been eyeing the senatorial seat of John Gear. His term expired in 1900, and at seventy-five years of age, his health was not good. It was assumed that he would not run a second time. But when it was announced that Albert B. Cummins would be a progressive candidate for the office before the General Assembly in January, the old order had reason for concern. Gear, in all probability, was the only man who could beat the magnetic Cummins even though the conservatives ostensibly had a safe majority in both houses of the legislature. It was customary to give a satisfactory public official a second term, and most of the newspapers would support him. Therefore, the party chieftains put Senator Gear, or "Old Business" as he was referred to, up for re-election.

Gear was physically unable to campaign in person. Iowa's outstanding young congressman, Jonathan P. Dolliver, an eloquent orator and slated to be McKinley's running-mate in 1896 before being requested to step aside so the New York

15 Bray, op.cit, pp. 42-43.

16 Joe R. Lane was a wealthy, independent lawyer from Davenport whose vote could not be bought. Lot Thomas was a progressive from Sioux City who did not long remain in congress. 
machine could sideline the troublesome Theodore Roosevelt, ${ }^{17}$ stumped the state in behalf of Gear's candidacy. Dolliver's speeches were direct attacks upon the high regard which many people held for Cummins, an upstart with a rebel following who would deprive an honorable statesman his deserving second term.

The facts that are known concerning this short but furious campaign indicate it hinged upon the election of the speaker of the house due to the advantage in patronage which would accrue. $^{18}$ D. H. Bowen was the Gear candidate, and W. L. Eaton had Cummins' support for this vital post. Resentment and bitter feelings were exhibited by partisans of both men, as if they belonged to rival parties.

Gardner Cowles, a new house member from Kossuth county, proved of great worth to the Gear and Bowen forces.

$\mathrm{He}$ ascertained that the number of members of the house committed to support Bowen for speaker fell short of the required majority. He counseled the round-robin method of signing up every possible man to a written agreement to vote for Bowen and Gear. This was immediately done, and then operations began, bringing influence to bear upon the wavering or undecided group. Members of the legislature and outsiders were utilized to accomplish these ends. Where necessary, promises were made of legislative patronage, committee chairmanships and assignments, and help in securing votes for bills to be introduced when the legislature assembled.19

The Cummins-Eaton leaders were equally active but not so methodical in their procedure. William G. Kerr, a member of the house from Grundy county, has described the pressure brought to bear upon himself and other Cummins supporters:

Some days before the holding of the caucus of Republican house members, James E. Blythe of Mason City, a former house member and brother of Joseph W. Blythe of Burlington, the latter the man who was always consulted by the public men of the state when any of its citizens were seeking important state office, together with George Metzger, postmaster at Davenport, took me into

17 William R. Boyd, "Jonathan P. Dolliver," ANNALs of IowA, XXIX (July, 1948), pp. 335-347.

18 Harrington, op.cit., p. 346.

19 William G. Kerr, "An Epoch in Iowa Politics," Annals of Iowa, XXXIII (January, 1956), pp. 158-159. 
a room in the old Savery hotel at Des Moines. In the course of a pleasant visit, they told me that the forces represented by them had been running Iowa political affairs and would continue to do so; that to oppose their strength was like "butting your head against a stone wall." I told them my mind was made up. This sort of pressure from outside my own district did not impress me too well. 20

The caucus session proved to be quiet and very businesslike in procedure, indicating how thorough had been the canvass made by the opposing factions. The legislative lines of the "standpatters" held. The vote was close but Dr. Bowen won the speaker's chair 43 to 38,41 votes being necessary for election. And Senator Gear was consequently re-elected.

So Cummins was again frustrated in his bid for the United States Senate. No doubt this second defeat was a major disappointment to his hopes and ambitions. But his stubborn supporters in the 28th General Assembly were to return to their home counties at the end of the session more determined than ever. They worked hard to improve and tighten the progressive organization of their communities in order to more effectively resume the battle the next year. Their labor at the grass-roots level was not in vain. For with their insistence that he again be their standard bearer in 1901, Cummins was destined to eventually reach his goal by way of the governorship.

On July 14, 1900, only five months after his re-election, Senator Gear died. It was the duty of Governor Shaw to appoint a successor for the remainder of the six-year term. Despite evidence that he had promised to support Cummins for the office, Shaw remained loyal to his friends, Judge Hubbard and the Northwestern line. When Gear was reelected in January, the governor had vigorously defended his administration against charges of favoritism. ${ }^{21}$

Actually Shaw greatly desired to be a senator himself. ${ }^{22}$ However, circumstances made it highly impractical at this time. It was imperative that the appointee be one capable of

20 Ibid, pp. 157-158.

21 "A Statesman's Career," The Sioux City Daily Tribune, January 17,1901 , p. 4.

22 Ibid, p. 4. 
being elected at the end of the short term, against Cummins or anyone else. The party's masters believed the dynamic Jonathan P. Dolliver to be the only logical choice, and instructed Shaw to so appoint him. Presumably Dolliver had also been promised the next senate vacancy for withdrawing as a vice-presidential candidate in favor of Theodore Roosevelt.

Apparently the governor was reluctant to appoint the choice of Hubbard and Blythe for personal reasons. He had disparaged Dolliver whose home was Fort Dodge, not far from his own in Denison, perhaps realizing that a successor to the aging Senator Allison would normally be chosen from the southern half of the state, a fact not favoring his own ambitions.

There is strong evidence to show that Shaw actually offered to name Blythe to the vacancy created by Gear's death. ${ }^{23}$ But the solicitor for the Burlington Railroad naturally preferred to exercise control from behind the scenes. And so Dolliver received the appointment, ironic in that he later altered his politics in tune with the changing times, and together with Cummins, provided strong progressive leadership in the United States Senate.

A state-wide progressive movement in Iowa continued to make progress in its struggle to gain control of the Republican party. Annual state elections occured in the fall of 1900. Two advocates of reform legislation were nominated, and elected to state office in November of that year. State senator Gilbert S. Gilbertson of Forest City and William B. Martin of Greenfield became state treasurer and secretary of state respectively. Openly aligned with the progressive group, their membership on the four-man executive council made the campaign for governor in 1901 even more important. Control of the council with its power to make assessments and dispense patronage would rest with the governor's vote.

Progressive leaders over the state determined to make an all-out fight for the governorship, particularly when Shaw's feelers for an unprecedented third term met with a decided

23 Letter to Emory H. English from a participant in a conference at the Congress hotel in Chicago where the suggestion was made, dated March 28, 1952. 
coolness. ${ }^{24}$ Their obvious candidate was the eminent Albert B. Cummins though he had little desire for the office. Former state senator, Lafe Young, editor of the Des Moines Capital, wanted the nomination, and had a sizeable progressive following. His series of editorials entitled "Wrecks Along the B \& Q Right-of-way" was a clever expose of the ruthless political pressure exercised by the Burlington lines.

Though Cummins' senatorial ambitions had been sidetracked twice by machine politics, he had not compromised with his political enemies. He opened a speech to a convention of Republicans in Polk county in February 1901, by saying, "Mr. Hubbard says that by the appointment of Dolliver the Republicans of Iowa have buried the hatchet. But where have they buried it? In me, gentlemen, in me."25

The announcement on February 9, 1901 that he would be a candidate for governor came only after he had been prevailed upon for several weeks to head the progressive group. Many felt, and so convinced Cummins, that only with his leadership, ability, and high repute could the governorship be captured as a first step to restoring democratic government in Iowa. Unalterably opposed to corruption and special privilege in any form, he again defied his party's ruling clique in consenting to serve the cause of reform.

The decision of Cummins to seek the governorship surprised the old hierarchy. They had anticipated that he would oppose Senator Allison for re-election in 1902. The fighting qualities he soon displayed as the inspired leader of a revitalized, more cohesive progressive organization was disconcerting. One must admire the man's adherence to principle and regard for all the people. It is said that he could have named his own price several times if he would forsake the faith and trust of his friends, but Cummins always "preferred to wear his own hat."26

The battle raged through the spring and summer in every

24 Emory H. English, "Men Who Led the Iowa Progressive Movement," an unpublished manuscript in the files of the Iowa State Department of History and Archives.

25 Addison Parker, "Cummins Whips the Old Machine," The Des Moines Sunday Register, September 21, 1930, p. 4.

26 Bray, op.cit., p. 57. 
local precinct and county convention during "Iowa's stormiest political campaign." An able and popular "standpatter" candidate was put forth in almost every strongly progressive county. There was a purpose behind the appearance of all these "straw" candidates. It was hoped they could prevent their opponents from sending a solidly pledged delegation to the state convention, as it was customary for favorite-son candidates to name their own county delegates. ${ }^{27}$

Cummins is reported to have spoken in every county of the state, his sincerity and championship of real representative government winning him wide support. Both factions fought to manipulate local caucuses. For example, in response to a call for help from one embattled local group, their state manager came to try and rescue the situation. A fire broke out in an old shack belonging to one of this faction's members, at exactly the time set for the caucus meeting. While practically all the local populace was thus diverted, a quorum of the opposition group met and named a bona-fide delegation. ${ }^{28}$

The resources of conservatism were formidable. Almost the entire congressional delegation in Washington; their postoffice and other appointees over the state; most doctors and lawyers; as well as the leaders of business stood against progressive republicanism at this time. The system's newspapers ridiculed the movement for reform. They had at their command most effective weapons for influencing delegations in unlimited finances and a standing offer of free transportation. With control of the State Central Committee, they picked Cedar Rapids, Hubbard's own city, as the site of the convention, to be held on August 7, 1901.

As the summer wore on only W. F. Harriman of Hampton, James H. Trewin of Cedar Rapids, and John Herriott of Stuart remained to oppose Cummins. The results of county conventions came in week by week, showing the progressives to be building up a gradual lead in total delegates. But the fight was stubborn and continued right up to the day and hour of the convention.

27 Interview with Emory H. English.

28 Emory H. English, "Evolution of Iowa Voting Practices," AnNaLs OF IowA, XXIX (April, 1948), p. 257. 
A study of this campaign shows it to be one of the first instances in which the corporation bosses allowed themselves to be put on the defensive. The issues had come to be clearly understood by the people. As the progressive movement gained momentum, a zeal for reform swept the state. The fire and enthusiasm of its leaders spread through the county organizations, bringing more and more local workers into their ranks.

The management of the Cummins forces was in the hands of Thomas A. Way of Mason City, Fred L. Maytag of Newton, G. S. Gilbertson of Forest City, H. W. Byers of Harlan, W. C. Hayward of Davenport, and Ed. D. Chassell of LeMars. An equally dynamic group coordinated the campaign from a Des Moines headquarters. They included Robert J. Fleming, Louis C. Kurtz, B. W. Garrett, Thos. J. Guthrie, Craig Wright, John McVicar Sr., Howard Clark, Emma K. Blaise, Ora Williams, Emory H. English, William J. Goodwin, John W. Dorr, John P. Cook, L. H. DeFord, and Chas. W. Steward. ${ }^{29}$

Many adherents who played an important part on the local and county level are unknown, if their identity was even made public at the time. Some individuals, of course, had been out in the open for years resisting the encroachment of the corporations in party management and the selection of public officials, while others preferred to work quietly toward a solution to the problem without incurring personal enmity. ${ }^{30}$

During the interval between the last county convention and the opening of the state convention, every effort was made to sway those delegates pledged to Cummins. But the unity he inspired could not be shaken. He and his supporters were accused of not being genuine Republicans, but fanatics and visionaries. Cummins said he wanted "to bring individual voters more into prominence and diminish the influence of permanent organization in the party." 31

The "radicals" did their work well. The convention nominated Cummins as the Republican candidate for governor on

29 Interview with Emory H. English.

30 Ibid.

31 The Weekly Iowa State Register (Des Moines), February 15, 1901. 
the first ballot. He was able to hold 866 delegates out of $1,641 . .^{32}$ Many "standpatters," believing the party to be wrecked, deserted the ticket in the November election. However, Cummins received enough votes to be elected governor, disrupting the dominance of a closed regime that had endured since the 1870 's. And with the assassination of McKinley on September 6, 1901, a man professing similar liberal views had become president of the United States.

Progressive leaders in Iowa with the personable and brilliant Cummins as their champion, put the state in the forefront of a movement that became nationwide. As governor, his advocacy of legislation prohibiting corporate contributions to political campaigns; the old unregulated caucus system; railroad passes and discriminating passenger rates; and corporate overcapitalization gained considerable publicity before the views of later political figures and writers who rode the wave of reform to prominence. ${ }^{33}$

Although an aroused electorate put Cummins in the governor's office in 1902, the "standpatters" retained a majority in the legislature, blocking the adoption of progressive measures into law. He found it necessary to fight for and win a third term before effective legislation could be passed. A clear mandate for political change was expressed by the people as early as 1901, but the struggle was to continue for several years.

The progressive movement in Iowa is to be distinguished from other similar and perhaps related movements of protest prior to the late 1890 's, and contemporary with it in other states. From its beginnings it was marked by a rebellion within the Republican party that gradually developed into a prolonged open struggle between two contending wings of the party to determine whether it would express the will of its members, or of special interests. Sincere and highly able men vigorously represented both factions.

A demand for reform developed under the leadership of a few perceptive men who had the courage to stake their reputations on what they believed to be right. With an un-

32 B. F. Gue, History of Iowa, III, 1903, pp. 206-207.

33 Harrington, op.cit., pp. 364-365. 
shakeable faith in their cause, they played a role that was indispensable in educating and awakening the public. But it is also true, in the opinion of Mr. Emory H. English, that:

No one man or small group was responsible for its development. The inception of the movement, its gathering of momentum, the determination of those engaged, the selection of a candidate to lead at important junctures, all contributed to its success. 34

34 "Men Who Led the Progressive Movement in Iowa," op.cit.

\section{Fire at the State Capitol}

Fire originating in the attic in the northwest corner of the State Capitol at 11:00 o'clock today did $\$ 250,000$ worth of damage and caused the indefinite postponement of the Twenty-ninth General Assembly. The fire it now seems started this morning at 8:00 o'clock in Committee room No. 5 off the house of representatives. The capitol building has recently been repaired and improved and this room was used for a store room for bits of lumber shavings, rubbish, paint and the like. The fire probably started from crossed electric wires. It evidently smouldered for a time and . . . then started again. A painter who was still working in the building found the blaze about 11.00 o'clock. It had crept up through the committee room into the attic and was eating its way over the ceiling and the attic above. A general fire alarm was turned in and the firemen were soon fighting the flames. At first it seemed that the flames were beyond control and that the entire structure was doomed.

The flames were not long in eating their way into the house of representatives. Here everything was ruined by fire, smoke and water. For some time the heat was so intense that it was impossible to get anywhere near the part of the building which was ablaze. Governor Cummins and every person in the building started working to save the records, books, old flags, etc. All of the records were saved and the large library is safe. Janitor S. J. Albers was quite seriously injured. He was overcome by the smoke and flames.-Boone Daily News, January 4, 1904. 
Copyright of Annals of Iowa is the property of State of Iowa, by \& through the State Historical Society of Iowa and its content may not be copied or emailed to multiple sites or posted to a listserv without the copyright holder's express written permission. However, users may print, download, or email articles for individual use. 